УДК 343.985.7

DOI https://doi.org/10.32837/yuv.v0i1.1616

\author{
О. Пучков \\ кандидат юридичних наук, \\ співробітник Служби безпеки України
}

\title{
С. Гордієнко
}

судовий експерт

\section{ОКРЕМІ АСПЕКТИ МЕТОДИКИ РОЗСЛІДУВАННЯ ЗЛОЧИНІВ У СФЕРІ БАНКІВСЬКОЇ ДІЯЛЬНОСТІ, ЩО ВЧИНЯЮТЬСЯ 3 ВИКОРИСТАННЯМ ФІКТИВНОГО КАПІТАЛУ}

\begin{abstract}
Невід'ємною складовою частиною економіки держави є банківська система, функціональними завданнями якої є забезпечення стабільності національної валюти та регулювання грошової маси, підтримка стійкості банківської діяльності та грошового ринку, забезпечення ефективного функціонування платіжної системи та цінової політики.

Для організації ефективного функціонування банківської системи загалом і роботи іï окремих елементів необхідним $€$ їх убезпечення від різних протиправних посягань, зокрема фінансових афер, зазвичай здійснюваних при різних банківських операціях.
\end{abstract}

Правопорушення у сфері банківської діяльності та їхні наслідки мають значний вплив на стан економічного благополуччя людини, суспільства та держави.

Так, ліквідація більш ніж дев'яноста банків України у період із 2014 по 2018 рр. підірвала фінансово-грошову систему України - населення втратило свої заощадження, підприємства й організації, у т. ч. державні, із втратою обігових коштів втратили можливість розвитку, збільшення товарообігу та залучення капітальних інвестицій, а завдані банкам збитки та девальвація національної грошової одиниці наблизили країну до дефолту.

Однією 3 передумов оголошення банкрутства та, як наслідок, ліквідації банків стало пропорційне збільшення регулятивних капіталів таких банків. Останнє, зокрема, було зумовлене можливістю збільшення залучених коштів у балансах банків, тобто депозитних вкладів населення, залишків на поточних рахунках юридичних осіб та інших кредиторів.

Як показує практика, у більшості банків до капіталу залучалися грошові кошти непрозорого походження, які надалі було залучено для здійснення різних банківських операцій та отримання на їх основі «дивідендів». Тобто здебільшого функціонування таких банків грунтувалося на реалізації фіктивних трансакцій і залучення фіктивного капіталу.

Тематика фіктивного капіталу банків зараз не має теоретичного й експертного дослідження. Водночас вона видається доволі цікавою та актуальною за сучасних умов і наших реалій.

Криміналістичне дослідження злочинів у банківській сфері, визначення основних тенденцій такої злочинності, вивчення окремих механізмів і способів вчинення правопорушень у банківській сфері є основою для розробки ефективних рекомендацій із їх розслідування.

Метою статті $є$ дослідження окремих аспектів методики розслідування злочинів у сфері банківської діяльності, що вчиняються 3 використанням фіктивного капіталу. Для досягнення 
поставленої мети необхідним $€$ виконання таких завдань:

- проаналізувати окремі способи вчинення злочину у банківській сфері 3 використанням фіктивного капіталу на основі висвітлення конкретних фінансових операцій, якими було забезпечено формування грошового ресурсу для збільшення статутного фонду банку та субординованого боргу, й опису бухгалтерських записів, котрими було забезпечено рух коштів;

- надати рекомендації правоохоронним органам щодо тактики проведення окремих слідчих дій, зокрема таких, що спрямовані на документальне фіксування фактів вчинення злочину, а також підготувати проєкт питань, на які повинен відповісти експерт у своєму висновку при проведенні судово-економічної експертизи;

- надати рекомендації правоохоронним органам щодо формування переліку первинних документів, що стануть основою у розслідуванні протиправних діiі, а також будуть доказами у справі.

Окремі питання фіктивного капіталу є об'єктом дослідження у роботах T. Владігерова, С. Леонова, В. Мандибури, Ю. Сапачука, О.О. Розинки, P.I. Шаравари й у дисертаційних дослідженнях A.M. Трещева «Фіктивний капітал: сучасні форми руху на фінансових ринках», О.О. Ласукової «Фіктивний капітал: економічна природа, носії і механізм державного регулювання», С.К. Кукліної «Фіктивний капітал і особливості його руху в сучасній економіці», Г.М. Богачової «Співвідношення реального і фіктивного капіталу» тощо.

Дослідженню методів розслідування окремих видів злочинів у сфері банківської діяльності присвячено роботи В.Д. Ларічева, В.М. Поповича, К. Фрумкіна, Г.О. Матусовського та дисертаційні дослідження С.С. Чернявського «Методика розслідування злочинів у сфері банківського кредитування» та «Теоретичні та практичні основи методики розслідування фінансового шахрайства», О.В. Курмана «Методика розслідування шахрайства
3 фінансовими ресурсами», I.I. Попович «Криміналістичне забезпечення обігу розрахункових документів у банківській системі 3 метою запобігання вчиненню злочинів», В.Д. Поливанюка «Особливості розслідування злочинів, вчинених у банківській системі Украіни 3 використанням сучасних інформаційних технологій», Л.В. Паламара «Криміналістична профілактика злочинів, пов'язаних із незаконним отриманням банківських кредитів» тощо.

Наше дослідження складатиметься з двох частин: y першій частині на основі матеріалів кримінального провадження буде описано механізм вчинення конкретного злочину у банківській сфері з використанням фіктивного капіталу, у другій частині буде надано рекомендації щодо тактики та методики розслідування такої категорії злочинів.

За сучасних умов загострення суспільно-політичних конфліктів, нестійкого економічного стану держави, зумовленого збільшенням рівня інфляції та девальвацією національної валюти, а також враховуючи тенденції злочинності (рівень латентності та «ціну» економічної злочинності, складовою частиною якої $€$ злочини у банківській сфері) та вдосконалення механізмів вчинення злочинів, особливо актуальним постає питання протидії та ефективного розслідування злочинів у банківській сфері.

Варто звернути увагу на те, що сучасні методики та рекомендації щодо розслідування злочинів, зокрема у банківській сфері, не $є$ пристосованими до сучасних викликів, оскільки не враховують практику застосування злочинцями новітніх засобів, способів і «схем» вчинення злочинів. Таким чином, необхідне розроблення окремих сучасних аспектів методики розслідування злочинів у банківській сфері, які грунтуються на матеріалах сучасної слідчої та судової практики.

У цьому дослідженні використовуватимуться саме матеріали слідчої практики - матеріали кримінального провадження, внесені до Єдиного 
реєстру досудових розслідувань за № 62019000000000450 від 05 квітня 2019 р., за ознаками вчинення кримінального правопорушення, передбаченого ч. 2 ст. 364 КK України. Так, Державним бюро розслідувань (далі ДБР) розпочало розслідування діяльності посадових осіб Національного банку України (далі - НБУ) протягом 2017-2019 рр. Про це йдеться в одній із ухвал слідчого судді Печерського районного суду м. Києва від 16 травня 2019 p. [6].

Що таке регулятивний капітал і фіктивний капітал?

Регулятивний капітал (regulatory capital) - один із найважливіших показників діяльності банків, основним призначенням якого $є$ покриття негативних наслідків різноманітних ризиків, які банки беруть на себе у процесі своєї діяльності, та забезпечення захисту вкладів, фінансової стійкості та стабільності банківської діяльності. Регулятивний капітал банку складається 3 основного та додаткового капіталу [4]. Отже, головними статтями регулятивного капіталу $€$ статутний фонд банку та залучений субординований борг.

Саме за цими двома статтями відбувалося фіктивне збільшення регулятивного капіталу банків, що є учасниками зазначеного кримінального провадження, а факти залучення останніми грошових коштів із зазначених джерел простежуються починаючи з 2000-х рр.

Процес збільшення регулятивного капіталу банку регулюється Постановою Правління НБУ № 368 від 28 січня 2001 р. [4], якою затверджено Інструкцію про порядок регулювання діяльності банків в Україні (далі - Інструкція). Крім того, Інструкцією встановлено порядок бухгалтерського обліку, документального підтвердження, пого- дження $з$ регулятором і реєстрації дій власників або інвесторів, спрямованих на збільшення статутного фонду або залучення субординованого боргу.

У свою чергу, фіктивний капітал (англ. fictive capital) - капітал, представлений у цінних паперах (акціях, облігаціях тощо), який дає право іхнім власникам регулярно присвоювати частину додаткової вартості у вигляді дивіденду або відсотка [1].

Проаналізуємо конкретний приклад збільшення статутного фонду та залучення субординованого боргу одного з банків, що було застосовано у механізмі вчинення злочину у досліджуваному кримінальному провадженні.

Насамперед варто зазначити, що для обліку грошових потоків, які брали участь у реалізації нижче описаних фінансових операцій, використовувалися класи, рахунки бухгалтерського обліку, затверджені Постановою Правління НБУ № 280 від 17 червня 2004 р. [3].

Рух грошових коштів, метою якого було збільшення статутного капіталу, розділимо на події (епізоди):

\section{Перша подія.}

10 жовтня 2010 р., ПАТ КБ «Банк» викуповує цінні папери у компаній TOB «1» на суму 50000 000,00 грн.

Переказ грошових коштів на поточні рахунки ТОВ «1» відбувається з рахунку обліку дебіторської заборгованості за операціями з цінними паперами Банку № 3541(1).

Відповідно до виписок по поточному рахунку ТОВ «1» № 2600(1) відкритому у ПАТ КБ «Банк», станом на 10 жовтня 2010 р. залишок грошових коштів на поточних рахунках складав 0,00 грн.

Зазначена фінансова операція підтверджується таким бухгалтерським записом, відображеним у виписці руху коштів по рахунку № 3541(1) (табл. 1).

Таблиця 1

\begin{tabular}{|c|c|c|c|c|c|}
\hline $\begin{array}{c}\text { № } \\
\text { документа }\end{array}$ & Дебет & Кредит & Контрагент & Сума & $\begin{array}{c}\text { Дата } \\
\text { проводки }\end{array}$ \\
\hline 178 & $3541(1)$ & $2600(1)$ & ТОВ «1» & 50000000,00 & 10.10 .2010 \\
\hline
\end{tabular}




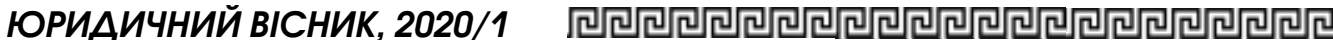

Дослідження процедури прийняття банком рішення про придбання цінних паперів необхідно проводити на підставі регламенту, встановленого внутрішніми положеннями та інструкціями, а також нормативних актів НБУ.

Відповідно до ст. 49 Закону України «Про банки і банківську діяльність» [2] здійснення операцій на ринку цінних паперів від свого імені розглядаються як кредитні.

Станом на 10 жовтня 2010 р. діяла Постанова Правління НБУ № 278 «Про затвердження Положення про порядок формування та використання резерву для відшкодування можливих втрат за кредитними операціями банків»[5], яка регулювала не тільки порядок розрахунку та бухгалтерські записи при формуванні резерву, а насамперед порядок визначення кредитоспроможності позичальників. Виконання вимог згаданої постанови було запорукою прозорого використання банком кредитних ресурсів і надійного захисту інтересів вкладників та інших кредиторів.

Друга подія включає в себе фінансові операції, якими забезпечено перетік коштів із поточного рахунку ТОВ «1» до зарахування ї до рахунку обліку капіталу ПАТ КБ «Банк».

За договором купівлі-продажу цінних паперів ТОВ «1» переказує 50000 000,00 грн відповідно на компанію - нерезидента ТОВ «2».

Зазначена фінансова операція підтверджується таким бухгалтерським записом, відображеним у виписці руху коштів по рахунку № 2600 (1) ТОВ «1» (табл. 2).
Оскільки відповідно до виписки руху коштів по рахунку ТОВ «2» залишок грошових коштів дорівнював 0,00 грн, слід зазначити, що зарахування 50000 000,00 грн від ТОВ «1» було єдиним джерелом коштів для здійснення подальших переказів.

$\mathrm{V}$ період із 30 грудня 2011 по 01 березня 2012 рр. ТОВ «2» розміщувало грошові кошти на депозитних рахунках, відкритих у ПАТ КБ «Банк», та отримало дохід у сумі 1000 000,00 грн.

За зазначений період відповідно до виписки руху коштів по поточному рахунку ТОВ «2», відкритому в ПАТ КБ «Банк», будь-яких зарахувань грошових коштів не відбувалося.

За рахунок повернутих із депозитного вкладу грошових коштів березня 2012 р. ТОВ «2» здійснює переказ 50000 000,00 грн на поточний рахунок ТОВ ЮК «3» як збільшення статутного фонду.

Зазначена фінансова операція підтверджується таким бухгалтерським записом (табл. 3).

Відповідно до виписки руху коштів по рахунку 2600. ТОВ ЮК «3», відкритому в ПАТ КБ «Банк», залишок грошових коштів складав 0,00 грн, що свідчить про те, що єдиним джерелом коштів, які були в розпорядженні одержувача для здійснення подальших операцій, були грошові кошти, отримані від ТОВ «2».

Із 01 березня 2012 по 01 квітня 2012 рр. ТОВ ЮК «3» розмістило отримані грошові кошти в сумі 50000 000,00 грн на депозитному рахунку, відкритому в ПАТ КБ «Банк», та отримало дохід в сумі 500 000,00 грн.

Таблиця 2

\begin{tabular}{|c|c|c|c|c|}
\hline $\begin{array}{c}\text { № } \\
\text { документа }\end{array}$ & Дебет & Кредит & Сума & $\begin{array}{c}\text { Дата } \\
\text { проводки }\end{array}$ \\
\hline 131 & $2600(1)$ ТОВ «1» & $2603(2)$ ТОВ «2» & 50000000,00 & 30.12 .2011 \\
\hline
\end{tabular}

Таблиця 3

\begin{tabular}{|c|c|c|c|c|}
\hline $\begin{array}{c}\text { № } \\
\text { документа }\end{array}$ & Дебет & Кредит & Сума & $\begin{array}{c}\text { Дата } \\
\text { проводки }\end{array}$ \\
\hline 765 & $2600 .(2)$ ТОВ «2» & $2600 .(3) 1$ ТОВ ЮК «3» 50000000,00 & 01.03 .2012 \\
\hline
\end{tabular}


01 квітня 2012 р. грошові кошти TOB ЮK «3» в сумі 50000 000,00 грн повертаються з депозитного рахунку на поточний, відкритий у ПАТ КБ «Банк». Відповідно до виписки руху коштів по поточному рахунку ТОВ ЮК «3», відкритому в ПАТ КБ «Банк», за зазначений період будь-яких зарахувань грошових коштів не відбувалося.

Того ж дня ТОВ ЮК «3» здійснює переказ 50000 000,00 грн на поточний рахунок ТОВ «4» як збільшення статутного фонду.

Зазначена фінансова операція підтверджується таким бухгалтерським записом (табл. 4).

Вхідний залишок грошових коштів відповідно до виписки на поточному рахунку № 2600.(4), відкритому для ТОВ «4», станом на 01 квітня 2012 р. дорівнював 7 229,43 грн.

У свою чергу, ТОВ «4» розміщують отримані грошові кошти на депозитному рахунку, відкритому в ПАТ КБ «Банк». Однак наступного дня, а саме 02 квітня 2012 р. грошові кошти 3 депозитного рахунку повертаються на поточний.

За рахунок повернутих із депозитного рахунку грошових коштів ТОВ «4» здійснює переказ $25000 \quad 000,00 \quad$ грн на користь банку на рахунок 3630 як внесок за незареєстрованим статутним капіталом.

Зазначена фінансова операція підтверджується таким бухгалтерським записом (табл. 5).

15 травня 2012 р. ПАТ КБ «Банк» зараховує суму внеску ТОВ «4» до капіталу, що підтверджується бухгалтерським записом (табл. 6).

Таким чином, встановлено та документально підтверджено, що збільшення статутного фонду ПАТ КБ «Банк» відбулося за рахунок грошових коштів, які Банк переказав на користь TOB «1» за цінні папери, емітентом яких була зазначена компанія.

Дослідженням фінансово-господарської діяльності ПАТ КБ «Банк» встановлено, що ТОВ «1» із засновників банку не виходило, свою частку в капіталі не зменшувало.

Того ж дня, а саме 15 травня 2012 р. грошові кошти в сумі 25000 000,00 грн, які залишилися у ТОВ «4» після збільшення статутного фонду ПАТ КБ «Банк», спрямовуються на рахунок обліку субординованого боргу, залученого ПАТ КБ «Банк», на підставі

\begin{tabular}{|c|c|c|c|c|}
\hline $\begin{array}{c}\text { № } \\
\text { документа }\end{array}$ & Дебет & Кредит & Сума & $\begin{array}{c}\text { Дата } \\
\text { проводки }\end{array}$ \\
\hline 48 & $2600 .(3)$ ТОВ ЮК «3» & $2600 .(4)$ ТОВ «4» & 50000000,00 & 01.04 .2012 \\
\hline
\end{tabular}

\begin{tabular}{|c|c|c|c|c|}
\hline $\begin{array}{c}\text { № } \\
\text { документа }\end{array}$ & Дебет & Кредит & Сума & $\begin{array}{c}\text { Дата } \\
\text { проводки }\end{array}$ \\
\hline 14 & $\begin{array}{c}2600(4) \\
\text { ТОВ «4» }\end{array}$ & $\begin{array}{c}\text { Внески за незареєстрованим } \\
\text { статутним капіталом }\end{array}$ & 25000000,00 & 02.04 .2012 \\
\hline
\end{tabular}

Таблиця 6

\begin{tabular}{|c|c|c|c|c|}
\hline $\begin{array}{c}\text { № } \\
\text { документа }\end{array}$ & Дебет & Кредит & Сума & $\begin{array}{c}\text { Дата } \\
\text { проводки }\end{array}$ \\
\hline 1352680 & $\begin{array}{c}\text { Внески за незареєстрованим } \\
\text { статутним капіталом }\end{array}$ & $\begin{array}{c}5000 \\
\text { Статутний } \\
\text { капітал банку }\end{array}$ & 25000000,00 & 15.05 .2012 \\
\hline
\end{tabular}


договору, погодженого Національним банком України, що підтверджується бухгалтерським записом (табл. 7).

Після закінчення діï договору про залучення субординованого боргу грошові кошти повертаються на рахунок ТОВ «4», що підтверджується наступним бухгалтерським записом (табл. 8).

Отримані від повернення ПАТ КБ «Банк» субординованого боргу грошові кошти ТОВ «4» використовує для надання позик співробітникам, здійснивши перекази на поточні рахунки фізичних осіб, відкриті в ПАТ КБ «Банк», що підтверджується такими бухгалтерськими записами (табл. 9).

Далі фізичні особи отримують готівкові грошові кошти зі своїх рахунків через касу відділення банку, що під- тверджується такими бухгалтерськими записами (табл. 10).

Таким чином, грошові кошти, за рахунок яких ПАТ КБ «Банк» придбав цінні папери, емітовані ТОВ «1», були легалізовані за допомогою операцій із цінними паперами, внесенням у статутні фонди товариств і надання субординованого кредиту ПАТ КБ «Банк». Фіналом цієї операції стало перетворення грошових коштів вкладників та інших кредиторів у неконтрольовані готівкові кошти та їх привласнення десятьма фізичними особами, які, будучи співробітниками ТОВ «4», входять до групи впливу кінцевого бенефіціара ПАТ КБ «Банк».

Третю подію ми присвячуємо дослідженню подальшого обліку варто-

Таблиця 7

\begin{tabular}{|c|c|c|c|c|}
\hline $\begin{array}{c}\text { № } \\
\text { документа }\end{array}$ & Дебет & Кредит & Сума & $\begin{array}{c}\text { Дата / час } \\
\text { проводки }\end{array}$ \\
\hline 1352680 & 2600 (4) ТОВ «4» & $\begin{array}{c}3660 \ldots \\
\text { Субординований борг }\end{array}$ & 25000000,00 & 15.05 .2012 \\
\hline
\end{tabular}

Таблиця 8

\begin{tabular}{|c|c|c|c|c|}
\hline $\begin{array}{c}\text { № } \\
\text { документа }\end{array}$ & Дебет & Кредит & Сума & $\begin{array}{c}\text { Дата / час } \\
\text { проводки }\end{array}$ \\
\hline 1352680 & $\begin{array}{c}3660 \ldots \\
\text { Субординований борг }\end{array}$ & 2600 (4) ТОВ «4» & 25000000,00 & 15.05 .2017 \\
\hline
\end{tabular}

Таблиця 9

\begin{tabular}{|c|c|c|c|c|}
\hline $\begin{array}{c}\text { № } \\
\text { документа }\end{array}$ & Дебет & Кредит & Сума & $\begin{array}{c}\text { Дата / час } \\
\text { проводки }\end{array}$ \\
\hline 1352680 & $2600(4)$ ТОВ «4» & 2620 (фіз. Особа) & 2500000,00 & 15.05 .2017 \\
\hline 1352680 & $2600(4)$ ТОВ «4» & 2620 (фіз. Особа) & 2500000,00 & 15.05 .2017 \\
\hline 1352680 & $2600(4)$ ТОВ «4» & 2620 (фіз. Особа) & 2500000,00 & 15.05 .2017 \\
\hline 1352680 & $2600(4)$ ТОВ «4» & 2620 (фіз. Особа) & 2500000,00 & 15.05 .2017 \\
\hline 1352680 & $2600(4)$ ТОВ «4» & 2620 (фіз. Особа) & 2500000,00 & 15.05 .2017 \\
\hline 1352680 & $2600(4)$ ТОВ «4» & 2620 (фіз. Особа) & 2500000,00 & 15.05 .2017 \\
\hline 1352680 & $2600(4)$ ТОВ «4» & 2620 (фіз. Особа) & 2500000,00 & 15.05 .2017 \\
\hline 1352680 & $2600(4)$ ТОВ «4» & 2620 (фіз. Особа) & 2500000,00 & 15.05 .2017 \\
\hline 1352680 & $2600(4)$ ТОВ «4» & 2620 (фіз. Особа) & 2500000,00 & 15.05 .2017 \\
\hline 1352680 & $2600(4)$ ТОВ «4» & 2620 (фіз. Особа) & 2500000,00 & 15.05 .2017 \\
\hline
\end{tabular}


Таблиця 10

\begin{tabular}{|c|c|c|c|c|}
\hline $\begin{array}{c}\text { № } \\
\text { документа }\end{array}$ & Дебет & Кредит & Сума & $\begin{array}{c}\text { Дата / час } \\
\text { проводки }\end{array}$ \\
\hline 1352680 & 2620 (фіз. Особа) & 1002 & 2500000,00 & 15.05 .2017 \\
\hline 1352680 & 2620 (фіз. Особа) & 1002 & 2500000,00 & 15.05 .2017 \\
\hline 1352680 & 2620 (фіз. Особа) & 1002 & 2500000,00 & 15.05 .2017 \\
\hline 1352680 & 2620 (фіз. Особа) & 1002 & 2500000,00 & 15.05 .2017 \\
\hline 1352680 & 2620 (фіз. Особа) & 1002 & 2500000,00 & 15.05 .2017 \\
\hline 1352680 & 2620 (фіз. Особа) & 1002 & 2500000,00 & 15.05 .2017 \\
\hline 1352680 & 2620 (фіз. Особа) & 1002 & 2500000,00 & 15.05 .2017 \\
\hline 1352680 & 2620 (фіз. Особа) & 1002 & 2500000,00 & 15.05 .2017 \\
\hline 1352680 & 2620 (фіз. Особа) & 1002 & 2500000,00 & 15.05 .2017 \\
\hline 1352680 & 2620 (фіз. Особа) & 1002 & 2500000,00 & 15.05 .2017 \\
\hline
\end{tabular}

Таблиця 11

\begin{tabular}{|c|c|c|c|c|}
\hline $\begin{array}{c}\text { № } \\
\text { документа }\end{array}$ & Дебет & Кредит & Сума & $\begin{array}{c}\text { Дата / час } \\
\text { проводки }\end{array}$ \\
\hline 17834233 & $3541(1)$ & 3541 (загальнобанківський) & 25000000,00 & 10.10 .2010 \\
\hline
\end{tabular}

сті цінних паперів, за рахунок викупу банком яких відбулося фінансування збільшення Статутного фонду.

Повертаючись до першої події, нагадаємо, що 10 жовтня 2010 p. ПАТ КБ «Банк» викуповує цінні папери у компаній ТОВ «1» на суму 25500000,00 грн.

За результатом зазначеної операції в балансі банку виникає дебіторська заборгованість, облік якої було віднесено на рахунок 3541 (загальнобанківський).

10 жовтня 2010 р. дебіторська заборгованість на рахунку $3541 \ldots$ відноситься на 3541(1) призначений для обліку дебіторської заборгованості саме ТОВ «1» у сумі 25500 000,00 грн.

Зазначена фінансова операція підтверджується таким бухгалтерським записом (табл. 11).

10 жовтня 2010 р. дебіторська заборгованість по рахунку 3541(1) закривається оприбуткуванням на рахунок № 3114(1), призначений для обліку вартості цінних паперів, емітованих ТОВ «1», суми 25501 000, 00 грн.
Надалі для створення ілюзіі ліквідності активів у балансі банку (цінні папери, вартість яких відображається на рахунку $3114 \ldots$ є банківським активом) здійснюються операції купівлі-продажу цінних паперів. До того ж, джерелом коштів, за рахунок яких відбувалося фінансування контрагентів за угодами, були грошові кошти банку.

Згадані фінансові операції вписуються в таку схему: банк укладає угоду купівлі-продажу цінних паперів із TOB «5» та переказує суму за угодою з рахунку обліку дебіторської заборгованості 3541 (загальнобанківський) на поточний рахунок ТОВ «1» № 2600(1), відкритий у ПАТ КБ «Банк». До того ж, сума переказу дорівнює вартості цінних паперів, яка вже обліковується на рахунку $3114(1)$ за раніше укладеною угодою з ТОВ «1».

За рахунок отриманих від банку грошових коштів ТОВ «1» здійснює придбання цінних паперів у ТОВ «5», переказавши грошові кошти 3 рахунку 2600(5) ТОВ «5» на рахунок 2600(1) ТОВ «1». У свою чергу, ТОВ «1» здійс- 
нює викуп цінних паперів, які знаходяться у власності банку та вартість яких обліковується на рахунку $3114(1)$. Зазначена операція супроводжується такими бухгалтерськими записами:

Дт 2600 ТОВ «1» Kт 2600 ТOB «5»; Дт 2600 ТОВ «5» КТ 3641 ПАТ «Банк»;

Дт 3641 ПАТ «Банк» Кт 3114 (nо субрахунку, відкритому для обліку вартості цінних паперів, емітованих $T O B$ «1» оприбуткованої за першою подією).

Фінальним записом зазначеного ланцюга фінансових операцій є запис по оприбуткуванню на баланс банку вартості цінних паперів у закриття дебіторської заборгованості за рахунком $3541 \ldots$, що відображається таким бухгалтерським записом: Дт 3114 (2) Кт 3541...

Описана схема руху грошових коштів може повторюватися неодноразово протягом декількох років.

За певний термін часу активів, створених внаслідок виведення з балансу грошових коштів, накопичується дуже багато. Однак настають обставини, які змушують власників і менеджмент банку вживати заходи, спрямовані на виведення 3 балансу вартість цінних паперів, емітенти яких мають ознаки фіктивності, визначені рішеннями Національної комісії з цінних паперів i фондового ринку, та набувають статусу токсичних активів.

Для виведення 3 балансу токсичних активів у вигляді цінних паперів банк укладає угоду купівлі-продажу з ТОВ «6».

Вартість цінних паперів 3 рахунку 3114 відноситься для обліку на рахунок $3541 \ldots$, відкритий для обліку дебіторської заборгованості покупця. Тобто в бухгалтерському обліку цінні папери передаються покупцю з відтермінуванням оплати.

Бухгалтерський запис: Дт $3541 \mathrm{KT}$ 3114 на суму вартості цінних паперів.

Паралельно 3 укладанням договору купівлі-продажу цінних паперів між банком і покупцем укладається договір іпотеки, яким забезпечується виконання договору купівлі-продажу. Предметом іпотеки, як показує практика, виступають земельні ділянки, призначені для ведення особистого фермерського господарства. Вартість земельних ділянок встановлювалася суб'єктом оціночної діяльності, та вона значно, в рази, перевищувала ринкову вартість.

Наступного дня після спливу терміну виконання угоди купівлі-продажу банк реалізує право іпотекодержателя та враховує вартість іпотеки в погашення дебіторської заборгованості за операцією з цінними паперами, виниклої за ТОВ «6».

Зазначена подія супроводжується таким бухгалтерським записом: Дт 3408 Кт 3541 на суму вартості оприбуткованої земельної ділянки.

Переоцінкою активів, проведеною для встановлення вартості ліквідаційної маси Банку, встановлюється дійсна вартість оприбуткованої земельної ділянки.

Розрахункова різниця між вартістю земельної ділянки при оприбуткуванні на баланс банку та вартістю, встановленою для розрахунку ліквідаційної маси, є розрахунковим збитком, сума якого відноситься на рахунок обліку операційних витрат № 7399 як знецінення активу, та наприкінці року зменшує капітал.

Після реалізації земельної ділянки збиток коригується залежно від суми грошових коштів, отриманих від продажу, що супроводжується фіксацією суми негативного результату від продажу активу.

Щодо рекомендацій про тактику та методику розслідування такої категорії злочинів, то суб'єкту розслідування варто звернути увагу на таке. Для документального підтвердження фінансово-господарських операцій, якими були завдані збитки, необхідно дослідити документи:

1. Юридичні документи ПАТ КБ «Банк», на підставі яких встановити повноваження як окремих посадових осіб, так і колегіальних органів на при- 
йняття рішень для проведення активних операцій.

2. Облікову політику ПАТ КБ «Банк», яка регулює використання стандартів бухгалтерського обліку та фінансової звітності при веденні активних операцій.

3. Кредитну політику ПАТ КБ «Банк», що регулює порядок здійснення активних операцій, і мінімізацію банківських ризиків.

4. Протокол Кредитного комітету ПАТ КБ «Банк», яким було надано дозвіл на придбання цінних паперів, емітованих ТОВ «1».

5. Документи, на підставі котрих відповідно до Кредитної політики банк приймав рішення щодо придбання цінних паперів, емітованих ТОВ «1».

6. Виписки руху коштів по рахунках, зазначених у ланцюгах бухгалтерських записів, що супроводжували фінансові операції.

7. Документи, на підставі яких НБУ надав дозвіл на включення внеску в статутний фонд до капіталу відповідно до Постанови Національного банку України № 368 від 28 січня 2001 р.

8. Юридичну справу ТОВ «1».

9. Звіти суб'єктів оціночної діяльності щодо оцінки вартості земельної ділянки на дату оприбуткування на баланс і на дату розрахунку ліквідаційної маси ПАТ КБ «Банк».

10. Договір купівлі-продажу цінних паперів із ТОВ «6».

11. Договір іпотеки.

12. Договір купівлі-продажу земельної ділянки.

Зазначений перелік документів не $€$ вичерпним i може бути доповненим, враховуючи обставини конкретної справи. Виходячи з описаних нами обставин, внаслідок протиправних дій службовими особами банку завдані збитки.

Ми пропонуємо перелік питань, які слідчому або прокурору необхідно поставити перед експертом:

1. Чи підтверджується документально, що 10 жовтня 2010 р. єдиним джерелом коштів на поточному рахунку
№ 2600(1), відкритому для ТОВ «1», були кошти, отримані від ПАТ КБ «Банк», за договором купівлі-продажу цінних паперів власної емісії?

2. Чи підтверджується документально закриття дебіторської заборгованості на балансі ПАТ КБ «Банк» по рахунку 3541(1), що виникла внаслідок перекату грошових коштів від ПАТ КБ «Банк» на користь ТОВ «1» в сумі 50000 000,00 грн, на рахунок № 3114 (1), призначений для обліку вартості цінних паперів, емітованих $\mathrm{TOB} \ll 1 » ?$

3. Чи підтверджуються документально бухгалтерські записи, якими супроводжувався рух коштів по рахунках TOB «1», ТOB «2», ТОВ «3», ТОВ «4» 3 дати переказу грошових коштів від ПАТ КБ «Банк» на рахунок ТОВ «1» у сумі 50000 000,00 грн, до дати переказу грошових коштів із рахунку TOВ «4» на рахунок № 3630 у сумі 25000 000,00 грн? Чи підтверджується документально, що в зазначених переказах використовувалися виключно грошові кошти, отримані ТОВ «1» від ПАТ КБ «Банк» у сумі 50000000,00 грн?

4. Чи підтверджується документально бухгалтерський запис, яким проведено включення грошових коштів, зарахованих на рахунок № 3630 від ТОВ «4», до капіталу ПАТ КБ «Банк», що обліковувався на рахунку № 5000?

5. Чи підтверджується документально, що збільшення статутного капіталу ПАТ КБ «Банк» у сумі 25000 000,00 грн відбулося виключно за рахунок грошових коштів ПАТ КБ «Банк»?

6. Чи підтверджується документально, що ТОВ «1» здійснив переказ грошових коштів у сумі 25000 000,00 грн на рахунок № 3660 як надання ПАТ КБ «Банк» субординованого кредиту? Чи підтверджується документально, що джерелом коштів для здійснення цієї операції були кошти, отримані ТОВ «1» внаслідок продажу банку цінних паперів власної емісії від 10 жовтня 2010 p.? 


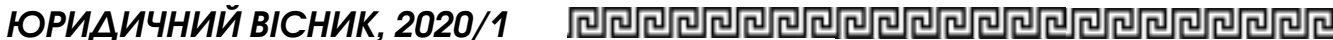

7. Чи підтверджується документально зміна рахунків обліку вартості цінних паперів, забезпеченого бухгалтерськими записами руху коштів по відповідних поточних рахунках юридичних осіб і рахунках обліку кредиторської та дебіторської заборгованості за операціями банку з цінними паперами, як зазначено актом перевірки?

8. Чи підтверджується документально віднесення суми вартості цінних паперів, емітованих ТОВ «1» 3 рахунку № 3114 (1) на рахунок обліку дебіторської заборгованості за операціями з цінними паперами № 3541(6) у сумі 25000000,00 грн?

9. Чи підтверджується документально, що дебіторська заборгованість, яка виникла по рахунку 3541(6) в сумі 25000 000,00 грн, була закрита оприбуткуванням вартості земельної ділянки на рахунок № 3408?

10. Чи підтверджується документально та розрахунково сума збитків, завданих банку (джерело збитків: або від знецінення активу, або як від’ємний результат продажу активу)?

11. Чи підтверджується документально повернення грошових коштів у сумі 25000 000,00 грн з рахунку обліку субординованого боргу № 3660 на рахунок ТОВ (1) № 2600(1)?

12. Чи підтверджується документально переказ 25000000,00 грн із поточного рахунку ТОВ (1) № 2600(1) на рахунки фізичних осіб?

13. Чи підтверджується документально, що фізичні особи отримали грошові кошти 3 рахунків, відкритих у ПАТ КБ «Банк» у касі відділення банку?

На основі дослідження матеріалів кримінального провадження було проаналізовано окремі способи вчинення злочинів у банківській сфері 3 використанням фіктивного капіталу. $\mathrm{У}$ роботі було висвітлено конкретні фінансові операції, що забезпечували формування грошового ресурсу для збільшення статутного фонду банку та субординованого боргу, перелічено основні «суб'єкти схеми» й описано алгоритм їхніх дій, а також проаналізовано бухгалтерські записи, якими забезпечувався рух коштів. Весь механізм руху коштів було розділено на три події (епізоди) та детально описано.

На основі здійсненого дослідження авторами запропоновано проєкт переліку питань, на які повинен відповісти експерт (у своєму висновку) при проведенні судово-економічної експертизи. Зазначений запропонований перелік містить тринадцять основних питань, що можуть бути поставлені експертом. Зазначено, що перелік таких питань не $є$ статичним і вичерпним, а повинен бути сформований індивідуально залежно від конкретних обставин вчинення злочину, слідчих ситуацій та основних версій. Цей перелік має виключно рекомендаційний характер.

На основі здійсненого дослідження авторами також запропоновано перелік первинних документів, котрі можуть стати основою в розслідуванні протиправних дії, а також доказами у справі. Зазначений запропонований перелік містить дванадцять основних пунктів. Перелічені документи є підтвердженням фінансово-господарських операцій, якими були завдані збитки. Зазначено, що перелік такої документації не $є$ універсальним для всіх випадків вчинення злочинів у банківській сфері, а повинен бути сформований індивідуально в кожній конкретній окремій ситуації.

На основі дослідження матеріалів кримінального провадження у статті було проаналізовано окремі способи вчинення злочинів у банківській сфері з використанням фіктивного капіталу. Дослідження складалося із двох частин: y першій частині на основі матеріалів кримінального провадження описано механізм вчинення конкретного злочину у банківській сфері з використанням фіктивного капіталу, у другій частині надано рекомендації щодо тактики та методики розслідування такої категорії злочинів.

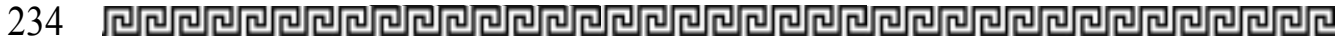


Обтрунтовується, що за сучасних умов загострення суспільно-політичних конфліктів, нестійкого економічного стану держави, зумовленого збільшенням рівня інфляиіі та девальвацією національної валюти, а також враховуючи тендениіі злочинності (рівень латентності та «ціну» економічної злочинності, складовою частиною якої є злочини у банківській сфері) та вдосконалення механізмів вчинення злочинів, особливо актуальним постає питання протидіi та ефективного розслідування злочинів у банківській сфері.

У роботі було висвітлено конкретні фінансові операціi, щзо забезпечували формування грошового ресурсу для збільшення статутного фонду банку та субординованого боргу, перелічено основні «суб'єкти схеми» й описано алгоритм їхніх дій, а також проаналізовано бухгалтерські записи, якими забезпечувався рух коштів. Весь механізм руху коштів було розділено на три подіi (епізоди) та детально описано.

На основі здійсненого дослідження авторами запропоновано проєкт переліку питань, на які повинен відповісти експерт (у своєму висновку) при проведенні судово-економічної експертизи. Зазначений запропонований перелік містить тринадиять основних питань, що можуть бути поставлені експертом. Зазначено, що перелік таких питань не є статичним і вичерпним, а повинен бути сформований індивідуально залежно від конкретних обставин вчинення злочину, слідиих ситуацій та основних версій. Цей перелік має виключно рекомендаційний характер.

На основі здіисненого дослідження авторами також запропоновано перелік первинних документів, що можуть стати основою в розслідуванні протиправних діï, а також доказами у справі. Зазначений запропонований перелік містить дванадиять основних пунктів. Перелічені документи є підтвердженням фінан- сово-господарських операцій, якими були завдані збитки. Зазначено, що перелік такої документації не $є$ універсальним для всіх випадків вчинення злочинів у банківській сфері, а повинен бути сформований індивідуально в кожній конкретній окремій cumyau̧iï.

Ключові слова: способи вчинення злочинів, банківська сфера, фіктивний капітал, тактика розслідування, методика розслідування.

Puchkov O., Gordienko S. Some aspects of the methodology of investigation of the crimes in the banking field, committed with the use of fictitious capital

Based on the study of the materials of the criminal proceedings, the article analyzed some ways of committing crimes in the banking sector with the use of fictitious capital. The study consisted of two parts: the first part describes the mechanism of committing a specific crime in the banking sector, committed with the use of fictitious capital, and the second part provides recommendations for tactics and methods of investigating this category of crimes.

It is substantiated that in modern conditions of aggravation of sociopolitical conflicts, unstable economic condition of the state due to rising inflation and devaluation of the national currency, as well as taking into account crime trends (level of latency and "price" of economic crime, which is a crime in banking) and improvement of mechanisms for committing crimes, especially the issue of counteraction and effective investigation of crimes in the banking sector.

The article highlights specific financial transactions that ensure the formation of cash resources to increase the authorized capital of the bank and subordinated debt, lists the main "subjects of the scheme" and describes the algorithm of their actions, as well as analyzes the accounting records that 


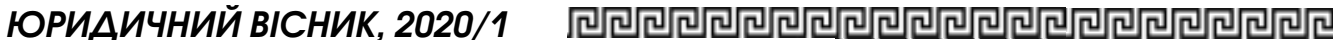

ensure cash flow. The whole mechanism of cash flow was divided into three events (episodes) and described in detail.

Based on the study, the authors proposed a draft list of questions to be answered by the expert (in his opinion) during the forensic economic examination. This proposed list contains thirteen main questions that can be asked by an expert. It is noted that the list of such issues is not static and exhaustive, but should be formed individually depending on the specific circumstances of the crime, investigative situations and basic versions. This list is for guidance only.

Based on the study, the authors also proposed a list of primary documents that can become the basis for the investigation of illegal actions, as well as evidence in the case. This proposed list contains twelve main items. These documents are evidence of financial and economic transactions that caused losses. It is noted that the list of such documentation is not universal for all cases of crimes in the banking sector, but should be formed individually in each situation.

Key words: ways of committing crimes, banking sphere, fictitious capital, tactics of investigation, methods of investigation.

\section{Література}

1. Завадський Й.С., Осовська Т.В., Юшкевич О.О. Економічний словник. Конdop, 2006. URL: http: / / library.nlu.edu.ua/ POLN_TEXT/KNIGI/KONDOR/EKONOMIC_ SL_2006.pdf.
2. Про банки і банківську діяльність : Закон України від 07 грудня 2000 р. № 2121 III. Верховна Рада України : офіційний вебcaŭm. URL: https: / / zakon.rada.gov.ua/ laws/show/2121-14\#n9.

3. Про Постанову Правління Національного банку України від 17 червня 2004 р. «Про затвердження Плану рахунків бухгалтерського обліку банків України та Інструкції про застосування Плану рахунків бухгалтерського обліку банків України» : Постанова Правління Національного банку України 17 червня 2004 р. № 280. Верховна Рада України : офіційний веб-сайm. URL: https://zakon.rada.gov. ua/laws / show / z0918-04.

4. Про Постанову Правління Національного банку України від 28 серпня 2001 р. «Про затвердження Інструкиії про порядок регулювання діяльності банків в Украіні» : Постанова Правління Національного банку України від 28 серпня 2001 р. № 368. Верховна Рада України : офіційний вебcaŭm. URL: https://zakon.rada.gov.ua/ laws / show / z0841-01.

5. Про Постанову Правління Національного банку України від 6 липня 2000 р. «Про затвердження Положення про порядок формування та використання резерву для відшкодування можливих втрат за кредитними операціями банків»: Постанова Правління Національного банку України 06 липня 2000 р. № 279. Верховна Рада Украӥни : офіційний веб-сайт. URL: https: / / zakon.rada.gov.ua/laws / show/ z0474-00.

6. Розслідування незаконної діяльності посадових осіб Нацбанку: подробиці. 2019. URL: https://legalhub.online/bankivske-ifinansove-pravo/ rozsliduvannya-nezakonnoyidiyalnosti-posadovyh-osib-natsbankupodrobytsi/https: //legalhub.online/ bankivske-i-finansove-pravo/rozsliduvannyanezakonnoyi-diyalnosti-posadovyh-osibnatsbanku-podrobytsi/. 